\title{
Growth responses of sugarcane to mycorrhizal spore density and phosphorus rate
}

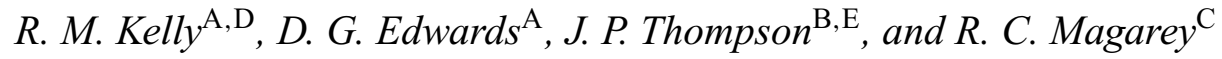

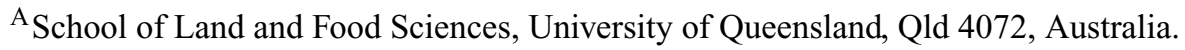 \\ ${ }^{B}$ Department of Primary Industries \& Fisheries, PO Box 2282, Toowoomba, Qld 4350, Australia. \\ ${ }^{\mathrm{C}}$ Bureau of Sugar Experiment Stations, PO Box 566, Tully, Qld 4854, Australia. \\ ${ }^{D}$ Current address: World Concern, PO Box 2938, Vientiane, Lao PDR. \\ ${ }^{\mathrm{E}}$ Corresponding author. Email: john.thompson@dpi.qld.gov.au
}

\begin{abstract}
Arbuscular mycorrhizal (AM) fungi, commonly found in long-term cane-growing fields in northern Queensland, are linked with both negative and positive growth responses by sugarcane (Saccharum spp.), depending on P supply. A glasshouse trial was established to examine whether AM density might also have an important influence on these growth responses. Mycorrhizal spores (Glomus clarum), isolated from a long-term cane block in northern Queensland, were introduced into a pasteurised low-P cane soil at 5 densities $(0,0.06,0.25,1$, 4 spores $/ \mathrm{g}$ soil $)$ and with $4 \mathrm{P}$ treatments $(0,8.2,25$, and $47 \mathrm{mg} / \mathrm{kg})$. At 83 days after planting, sugarcane tops responded positively to $\mathrm{P}$ fertilizer, although responses attributable to spore density were rarely observed. In one case, addition of 4 spores $/ \mathrm{g}$ led to a $53 \%$ yield response over those without AM at $8 \mathrm{mg} \mathrm{P} / \mathrm{kg}$, or a relative benefit of $17 \mathrm{mg} \mathrm{P} / \mathrm{kg}$. Root colonisation was reduced for plants with nil or $74 \mathrm{mg} \mathrm{P} / \mathrm{kg}$. For those without AM, P concentration in the topmost visible dewlap (TVD) leaf increased significantly with fertiliser $\mathrm{P}(0.07 v .0 .15 \%)$. However, $\mathrm{P}$ concentration increased further with the presence of AM spores. Irrespective of AM, the critical P concentration in the TVD leaf was $0.18 \%$. This study confirms earlier reports that sugarcane is poorly responsive to AM. Spore density, up to 4 spores/g soil, appears unable to influence this responsiveness, either positively or negatively. Attempts to gain P benefits by increasing AM density through rotation seem unlikely to lead to yield increases by sugarcane. Conversely, sugarcane grown in fields with high spore densities and high plant-available P, such as long-term cane-growing soils, is unlikely to suffer a yield reduction from mycorrhizal fungi.
\end{abstract}

Additional keywords: critical P concentration, mycorrhizal dependency, P nutrition, AM colonisation.

\section{Introduction}

In tropical northern Queensland, sugarcane (Saccharum interspecific hybrid) is grown on a range of soils that vary in their capacity to release and sorb phosphorus (P). In part, this is simply related to soil type and texture. Soils of the lower Herbert Valley, for example, vary in both the capacity of the soil to sorb $\mathrm{P}$, and in the ongoing reaction between sorbed P and the soil (Wood 1988; Bramley et al. 1995, 1996, 2003). Despite the effect this has on the supply of $\mathrm{P}$ to the crop, the industry recommends a uniform approach to $P$ fertiliser management throughout Queensland (Calcino 1994).

History of $\mathrm{P}$ application has also modified the availability of $\mathrm{P}$ in these cane-growing soils (Bramley et al. 1996). For soils with a limited history of $\mathrm{P}$ use, crops grown on high $\mathrm{P}$-sorbing soils require more $\mathrm{P}$ than those grown on low sorbing soils due to their greater capacity to retain $P$. However, high P-sorbing soils with a history of $\mathrm{P}$ application will have a greater capacity to supply $\mathrm{P}$ to crops over a longer period than low sorbing soils (Bramley et al. 2003). The practice of over-fertilising appears to be commonplace throughout the sugar industry, which has raised concerns about the downstream effect of fertilisers including $\mathrm{P}$ on the Great Barrier Reef lagoon (Bramley and Wood 1996; Bramley and Roth 2002).

The fact that most Queensland cane-growing soils have high supplies of plant-available P may indicate that symbiotic fungi known as AM (or arbuscular mycorrhizal fungi) play an inconsequential role in $\mathrm{P}$ acquisition by sugarcane. However, field surveys in northern Queensland clearly demonstrate that AM commonly persist in long-term cane-growing soils, and associate with cane roots (Magarey, pers. comm.; Kelly 1999). A $10 \%$ reduction in the dry weight was reported by Kelly et al. (2001) when young sugarcane plants, grown in soil amended with $240 \mathrm{~kg} / \mathrm{ha} \mathrm{P}$ equivalent, were inoculated with AM taken from long-term cane-growing soils. This 
slight loss in yield was unrelated to $\mathrm{P}$ insufficiency, and appeared to be due to a poorly symbiotic AM isolate. Narrowing of mycorrhizal communities, evident after longterm monoculture, may directly contribute to reductions in crop yield (Modjo and Hendrix 1986; Johnson and Pfleger 1992; Johnson 1993). The possibility that this mechanism is in action in the northern Queensland cane industry has been raised (Magarey 1996).

One factor that may influence the expression of a mycorrhizal association on plant growth is the density of AM propagules available to roots. Under symbiotic conditions, plants that receive more propagules at sowing are likely to be colonised earlier and more rapidly, leading often to improved growth and P-uptake over those with fewer propagules (Thompson 1994; Smith and Read 1997). A similar but negative relationship may take place where conditions favour pathogenicity, leading to a yield reduction if propagule numbers reach a critical density.

We wished to examine the sugarcane association with AM for a range of propagule densities and under varying $\mathrm{P}$ supplies. This may help to assess the importance of AMassociated yield reductions in the cane industry.

\section{Materials and methods}

\section{Inoculum source and preparation}

Mycorrhizal spores were retrieved from a long-term cane-growing field near Hewitt, northern Queensland $\left(17.97^{\circ} \mathrm{S}, 145.93^{\circ} \mathrm{E}\right.$; Fig. 1), where yield decline had been previously identified. Single-spore accessions were established, using sugarcane as the host species, within sand pot-cultures at both BSES, Hewitt, and at the University of Queensland $\left(27.48^{\circ} \mathrm{S}, 153.01^{\circ} \mathrm{E}\right)$ over an 8-12-month period. Spores from 4 of these accessions, each identified as Glomus clarum (S. Bentivenga, pers. comm.) (synonymous with Gl. manihotis, INVAM 2002), were extracted via a wet-sieving and decanting procedure, capturing fungal spores on a $125-\mu \mathrm{m}$ mesh sieve. This material was twice-clarified by water centrifugation, at $700 \mathrm{G}$ for $2 \mathrm{~min}$, to remove suspended organic matter (Tommerup 1992). Spores were surface-sterilised with chloramine-T (2\%), then stored at $4{ }^{\circ} \mathrm{C}$ in a filtersterilised streptomycin solution $(0.2 \%)$ (Fiske and Thompson 1988). The density of spores within this solution was determined by counting those spores present in replicate $1-\mathrm{mL}$ aliquots taken whilst the suspension was being stirred at $c .300 \mathrm{rpm}$.

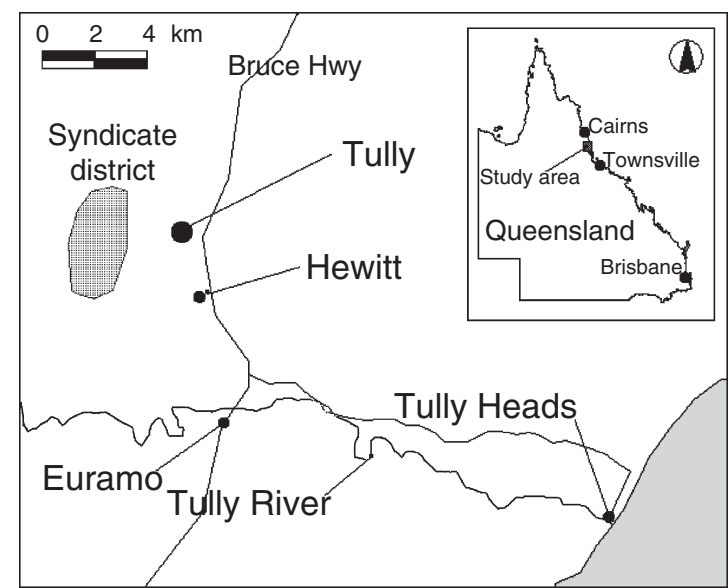

Fig. 1. Location of Syndicate district and Hewitt, northern Queensland, from where low-P cane-growing soil and mycorrhizal spores were obtained in 1996.

\section{Preparation of soil and planting material}

The soil prepared for use in the pot experiment was a silty-clay loam taken to a depth of $15 \mathrm{~cm}$ from a freshly cleared cane-growing field at 'Nicotra' in the Syndicate district near Tully. The soil was a Dermosol (Isbell 1996) within the Tully-Coom series (Cannon et al. 1992). A comprehensive list of the soil chemical properties has been presented by Kelly et al. (2001). Briefly, the soil was found to be deficient in P, potassium $(\mathrm{K})$, calcium $(\mathrm{Ca})$, magnesium $(\mathrm{Mg})$, and zinc $(\mathrm{Zn})$ for adequate sugarcane growth (Table 1). A composited sample, collected to $15 \mathrm{~cm}$ on 7 August 1996, was passed through a 25-mm-diam. mesh sieve, then steam-pasteurised at $70^{\circ} \mathrm{C}$ for $30 \mathrm{~min}$ to eliminate indigenous AM propagules (Thompson 1990).

Confirmation that steam-pasteurisation had also eliminated parasitic nematodes was checked by placing three $200-\mathrm{mL}$ samples of fresh and steamed soil into Whitehead trays to extract nematodes (Whitehead and Hemming 1965). Only non-parasitic nematodes (i.e. those with no root-piercing stylet) were found in the fresh soil in low numbers $(<200$ per $\mathrm{kg})$, and nematodes were not found in the steamed soil.

The steamed soil (2.6 kg oven-dry (OD) soil per pot, initial water content $10 \%$ ) was added into polythene-lined 18 -cm-diam. pots after mixing with basal nutrients and the $P$ treatment. Phosphorus rates were 0 , $8.2,25$, and $74 \mathrm{mg} / \mathrm{kg}$ applied as powdered $\mathrm{Ca}\left(\mathrm{H}_{2} \mathrm{PO}_{4}\right)_{2} \cdot \mathrm{H}_{2} \mathrm{O}$. The basal nutrients, nitrogen $(\mathrm{N}), \mathrm{K}, \mathrm{Mg}$, and iron $(\mathrm{Fe})$, were added in solution as $\mathrm{NH}_{4} \mathrm{NO}_{3}, \mathrm{~K}_{2} \mathrm{SO}_{4}, \mathrm{MgSO}_{4} .7 \mathrm{H}_{2} \mathrm{O}$, and $\mathrm{FeSO}_{4} .7 \mathrm{H}_{2} \mathrm{O}$ to provide 120,200 ,

Table 1. Chemical properties $(0-15 \mathrm{~cm})$ of the cane-growing soil from Nicotra, northern Queensland, determined prior to steam pasteurisation

Analyses were conducted at The University of Queensland, except for Zn, which was obtained by Incitec. Methods refer to those in Rayment and Higginson (1992). A comprehensive list of soil chemical properties is found in Kelly et al. (2001)

\begin{tabular}{lllllc}
\hline Property & Unit & Value & $\begin{array}{l}\text { Critical } \\
\text { value }\end{array}$ & Extractant & Method \\
\hline $\mathrm{P}$ & $\mathrm{mg} / \mathrm{kg}$ & 4 & 6 & $0.005 \mathrm{M} \mathrm{H}_{2} \mathrm{SO}_{4}$ & $9 \mathrm{G} 1$ \\
$\mathrm{~K}$ & $\mathrm{cmol}(+) / \mathrm{kg}$ & 0.06 & 0.24 & $1 \mathrm{M} \mathrm{NH} \mathrm{OAc}_{4}$ & $15 \mathrm{E} 1$ \\
$\mathrm{Ca}$ & $\mathrm{cmol}(+) / \mathrm{kg}$ & 0.16 & 0.55 & $1 \mathrm{M} \mathrm{NH} \mathrm{OAc}_{4}$ & $15 \mathrm{E} 1$ \\
$\mathrm{Zn}$ & $\mathrm{mg} / \mathrm{kg}$ & 0.6 & 0.6 & $0.1 \mathrm{M} \mathrm{HCl}$ & Reghenzani (1993) \\
\hline
\end{tabular}

${ }^{\mathrm{A}}$ Critical values are cited from Calcino (1994). 
18 , and $9 \mathrm{~kg} / \mathrm{ha}$ equivalent, respectively. Sulfur (S) additions, via the $\mathrm{SO}_{4}{ }^{2-}$ salts, provided $113 \mathrm{~kg} /$ ha equivalent. Calcium was added as powdered lime $\left(\mathrm{CaCO}_{3}\right)$ to provide $382 \mathrm{~kg} /$ ha equivalent. Pots were incubated for 15 days before AM spores were added. The surface layer of each pot (550g OD soil) was set aside, and the remainder mixed with sufficient inoculum suspension to provide either $0,0.06,0.25$, 1 , or 4 spores/g OD soil. These rates were lower than planned due to fewer spores retrieved than expected from the pot cultures. The surface layer $(c .25 \mathrm{~mm})$ was replaced following inoculation.

Sugarcane stems of Q124, confirmed to be free of ratoon-stunting disease (D. Teakle, pers. comm.), were taken from a plant-cane site near Gilberton, south-eastern Queensland $\left(27.75^{\circ} \mathrm{S}, 153.27^{\circ} \mathrm{E}\right)$. The stems were aseptically chopped into single-eye setts not more than $5 \mathrm{~cm}$ in length. Setts were surface-sterilised with $1 \%$ bleach $(5 \%$ available- $\mathrm{Cl}$ as $\mathrm{NaOCl}$ ) for $10 \mathrm{~min}$, then double-rinsed in sterile distilled water, and placed into a tray of polythene beads, previously rinsed with the bleach solution, placed inside a misting chamber with a continuous supply of deionised water for 3 days. Each sett received $c$. $3 \mathrm{~g}$ of powdered gypsum $\left(\mathrm{CaSO}_{4} \cdot 2 \mathrm{H}_{2} \mathrm{O}\right)$ at this time to promote sett germination.

Single setts were planted into each prepared pot at a depth of $2 \mathrm{~cm}$. Setts were stratified to block the effects should $\mathrm{P}$ variation due to node position exist within the stem. In this way, any one replicate was planted with setts originating from the same nodal numbers. Pots were planted on 6 November 1996. At 12 days after planting, germination was $94 \%$; pots that did not germinate were replanted with setts that had remained in the misting chamber.

\section{Experimental design}

The experiment consisted of sugarcane grown with factorial treatments of 4 rates of fertiliser $\mathrm{P}(0,8.2,25,74 \mathrm{mg} / \mathrm{kg})$ by 5 densities of $\mathrm{AM}$ spores $(0,0.06,0.25,1,4$ spores $/ \mathrm{g})$. Four replicates were prepared, and the 20 pots for each replicate were arranged on separate benches in a randomised complete block design. The position of pots within blocks and the position of blocks within the glasshouse were randomised weekly.

\section{Growth conditions}

To prevent soil mite and aphid infestations, Temik (a.i. aldicarb, $10 \% \mathrm{w} / \mathrm{w}$ ) was introduced into the surface soil at a rate of $2 \mathrm{~kg}$ a.i./ha on 19 November. Sterilised plastic beads were placed onto the soil surface at this time to slow surface evaporation and encourage roots to explore the entire pot. Pots were watered to $90 \%$ field capacity $\left(\theta_{\mathrm{g}}=33 \%\right)$ at planting, and twice weekly during the trial with daily applications approximating that moisture. Mean ambient temperature ranged between $25^{\circ} \mathrm{C}$ and $34^{\circ} \mathrm{C}$ for the duration of the trial (6 November 1996-28 January 1997).

From 3 weeks after planting, fortnightly applications of $40 \mathrm{~kg} \mathrm{~N} / \mathrm{ha}$ equivalent, as $\mathrm{NH}_{4} \mathrm{NO}_{3}$ in solution, were made for the duration of the trial. Copper $\left(\mathrm{Cu}\right.$, as $\left.\mathrm{CuSO}_{4} \cdot 5 \mathrm{H}_{2} \mathrm{O}\right)$ and boron $\left(\mathrm{B}\right.$, as $\left.\mathrm{H}_{3} \mathrm{BO}_{3}\right)$ nutrient solutions were added to each pot at 54 days after planting to supply 5 and $0.5 \mathrm{~kg} /$ ha equivalent, respectively, to overcome suspected nutrient deficiencies.

\section{Harvest methodology}

Plants were harvested at 83 days after planting. Deficiency symptoms and plant heights (base of the stem to the base of the topmost visible dewlap (TVD) leaf) were recorded. Tops were harvested and dried at $65^{\circ} \mathrm{C}$ for 7 days to determine dry weight. The soil mass was split longitudinally along the sett, and one half was rinsed briskly. A $1.5-\mathrm{g}$ subsample of fine roots was taken randomly from the root bolus and stored in $10 \%$ ethanol for mycorrhizal assessment. Remaining roots were assigned a fine root index (FRI) within replicates, a relative value that ranges between 1 (those with the least percentage of fine secondary and tertiary roots) and 5 (those with the maximum percentage of fine roots present). Roots were then oven-dried to determine root dry weight.

The 1.5-g root subsamples were stained (Phillips and Hayman 1970) for quantitative assessment of mycorrhizal infection (Giovannetti and Mosse 1980). Plant responsiveness to AM was measured by the relative mycorrhizal dependency (RMD, \%) (Plenchette et al. 1983):

$$
\mathrm{RMD}=\left(\frac{\text { dry weight of tops }(+\mathrm{AM})-\text { dry weight of tops }(-\mathrm{AM})}{\text { dry weight of tops }(+\mathrm{AM})}\right) \cdot 100
$$

Sugarcane index tissue, the middle $200 \mathrm{~mm}$ of the TVD leaf excluding the midrib (Calcino 1994), was digested in a nitric/perchloric acid solution (Johnson and Ulrich 1959). Concentrations of P, K, Mg, $\mathrm{Ca}, \mathrm{Fe}, \mathrm{Zn}$, and $\mathrm{Cu}$ were determined using inductively coupled plasma atomic emission spectroscopy.

\section{Statistical analyses}

Analysis of variance (ANOVA) was used to determine the effects of glasshouse treatments. Means were compared, using the protected least significant difference (1.s.d.) procedure, where the $F$-test was found to be significant $(P<0.05)$. An $\arcsin$ transformation prior to ANOVA was performed on the percent root infection data to achieve homogeneity of variance around the means. Regression analysis was used to derive polynomial models that described the P relationships. All statistical analyses were performed with Genstat.

\section{Results}

\section{Growth of plant tops}

Sugarcane plants grown without $\mathrm{P}$ fertiliser, irrespective of the spores applied, displayed symptoms typical of P deficiency, viz. poor tillering, shorter internodes, increased necrosis of older leaves, and reddening of the lower stem (Calcino 1994). These symptoms were milder on plants that received $8.2 \mathrm{mg} \mathrm{P} / \mathrm{kg}$.

Plants grew taller in response to increased rates of $\mathrm{P}$ fertiliser (Fig. 2). For example, plants that received nil $\mathrm{P}$ were $130-170 \mathrm{~mm}$ shorter at harvest than those that received $74 \mathrm{mg} \mathrm{P} / \mathrm{kg}$. Plants increased linearly in height from as soon as 21 days after planting, and differences in height between $P$ treatments were evident at every measurement. Apart from modest height differences early on, there was no significant effect $(P<0.05)$ of spore density.

Responses by dry weight of tops to spore density varied with $\mathrm{P}$ supply (Fig. $3 a$ ). Plants that received 0 , 25, or $74 \mathrm{mg} \mathrm{P} / \mathrm{kg}$ did not respond significantly $(P=0.05)$ to AM. Some plants that received $8.2 \mathrm{mg} \mathrm{P} / \mathrm{kg}$ responded positively to AM (up to $53 \%$ with 4 spores $/ \mathrm{g}$ ).

Dry weight loss due to insufficient $\mathrm{P}$ was severe; all plants without $\mathrm{P}$ produced, on average, just over one-third that of all plants that received $74 \mathrm{mg} \mathrm{P} / \mathrm{kg}(16.3$ v. $43.9 \mathrm{~g} ; P<0.001)$. Partial ANOVA (i.e. comparison of plants that received either nil or 4 spores/g) showed that the addition of 4 spores $/ g$ led to significantly greater $(P=0.03)$ dry weight of tops (30.9v. $33.3 \mathrm{~g} / \mathrm{pot})$. 


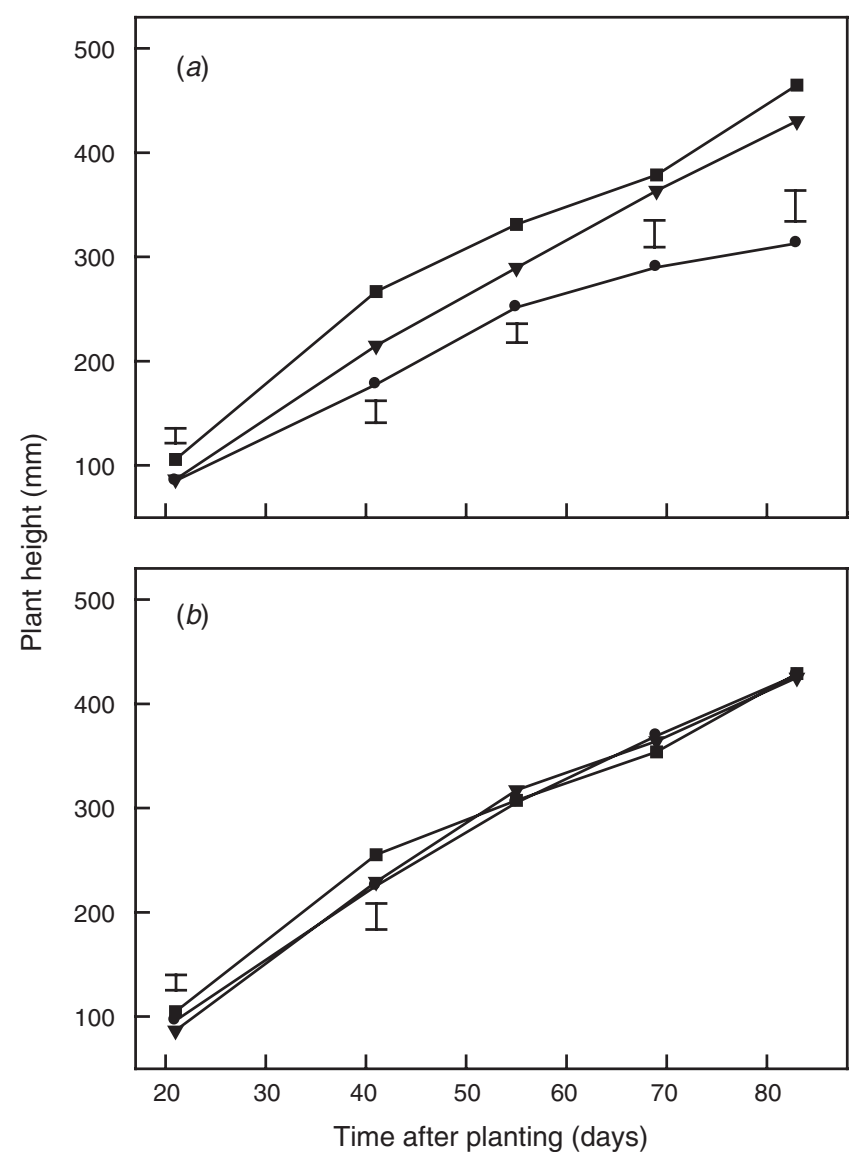

Fig. 2. Plant height of sugarcane grown with (a) 3 rates of $P$ fertiliser $(0,8.2,74 \mathrm{mg} \mathrm{P} / \mathrm{kg} ; \boldsymbol{\bullet}, \mathbf{\nabla}, \mathbf{\square}$, respectively) and $(b) 3$ densities of AM spores $(0,0.25,4$ spores/g; $\bullet, \boldsymbol{\nabla}, \mathbf{\square}$, respectively). Vertical bars represent the 1.s.d. $(P=0.05)$ at a given time; missing l.s.d. bars indicate that the differences at that time were not significant.

Fertiliser savings attributable to AM were rarely evident. In one instance, plants that received 4 spores/g and $8.2 \mathrm{~kg} \mathrm{P} / \mathrm{kg}$ produced $53 \%$ more dry weight of tops than non-mycorrhizal plants at the same $\mathrm{P}$ level. This was equivalent to that of non-mycorrhizal plants that received $25 \mathrm{mg} \mathrm{P} / \mathrm{kg}$, indicating a relative saving of $17 \mathrm{mg} / \mathrm{kg}$ (Fig. 3a).

Dry weight responses by sugarcane plants to $\mathrm{P}$ fertiliser for each of the spore density treatments were described using the Mitscherlich equation:

$$
y=a-b \cdot c^{x}
$$

where $y$ refers to the dry weight of tops (g/pot) and $x$ refers to the rate of $\mathrm{P}$ applied $(\mathrm{mg} / \mathrm{kg})$. The value $a$ indicates the maximum dry weight for that spore density treatment, and the difference ' $a-b$ ' is the dry weight of plant tops without $\mathrm{P}$. Dry weights of sugarcane tops at 83 days after planting peaked when $\mathrm{AM}$ were added at 0.06 spores $/ \mathrm{g}$ but were lowest with the addition of 4 spores $/ \mathrm{g}(50.7 v .42 .1 \mathrm{~g} / \mathrm{pot})$ (Table 2). Without $\mathrm{P}$ addition (i.e. $a-b$ ), dry weight was poorest for plants that received no AM but was maximal with the addition of 1 spore/g (14.2v. $17.8 \mathrm{~g}$, respectively).

The combined effects for all spore and fertiliser treatments could be described by the single Mitscherlich regression:

$$
y=45.2-29.8 \cdot 0.93^{x}\left(r^{2}=0.90 ; n=20 ; P<0.001\right)
$$

This relationship indicates that the addition of $26 \mathrm{mg} \mathrm{P} / \mathrm{kg}$ (c. $28 \mathrm{~kg} / \mathrm{ha}$ ) would, irrespective of AM, provide sufficient $\mathrm{P}$ for near-optimal (i.e. $90 \%$ of maximum) growth.

Sugarcane plants produced on average between 3 and 5 tillers per plant (Table 3). Tillering responded only to the highest rate of $\mathrm{P}$ fertiliser $(P<0.001)$.

\section{Root growth parameters}

Root weight ratio, or the root dry weight relative to the whole plant dry weight, was erratic. Root weight ratio of mycorrhizal plants ranged from $43(0.06$ spores $/ g$, nil fertiliser) to 24 ( 0.25 spores $/ \mathrm{g}, 74 \mathrm{mg} \mathrm{P} / \mathrm{kg})$, but treatment trends were clearly not observed (Fig. $3 b$ ).

Mycorrhizal colonisation was generally dependent on spore presence (but not necessarily spore density) and $\mathrm{P}$ rate (Fig. $3 c$ ). Colonisation levels $(\arcsin \sqrt{ } \%)$ remained $<22 \%$ for all plants without $\mathrm{P}$, whereas mycorrhizal plants that received $25 \mathrm{mg} \mathrm{P} / \mathrm{kg}$ had $>30 \%$. At the highest $\mathrm{P}$ rate, colonisation was limited to $<30 \%$. Some plants without AM spores had a slight root colonisation but this was not significantly greater than zero $(P=0.05)$.

Only when $25 \mathrm{mg} \mathrm{P} / \mathrm{kg}$ was applied and spores were present at 0.25 spores $/ \mathrm{g}$ or higher did plants produce greater amounts $(P<0.001)$ of infected root weight than the non-mycorrhizal control (Fig. $3 d$ ). Plants that received $25 \mathrm{mg} \mathrm{P} / \mathrm{kg}$ and 0.25 spores $/ \mathrm{g}$ produced almost 5 -fold the infected root weight of those with $74 \mathrm{mg} \mathrm{P} / \mathrm{kg}$ and 4 spores $/ \mathrm{g}$ $(11.7$ v. $2.4 \mathrm{~g})$. The variation in infected root weight was more diminished when plants received either nil or $74 \mathrm{mg} \mathrm{P} / \mathrm{kg}$.

Fine root index of plants responded to $P$ fertiliser (Table 3 ). Addition of $25 \mathrm{mg} \mathrm{P} / \mathrm{kg}$ improved FRI $(P<0.001)$ from 2.0, for those that received nil fertiliser $\mathrm{P}$, to 3.7. Fine root index and the infected root weight were poorly correlated $\left(r^{2}=0.17 ; n=80 ; P<0.001\right)$.

\section{Responsiveness to AM}

Responsiveness (\%) of sugarcane to AM colonisation was calculated for each treatment combination using Eqn 1.

Plants most responsive to AM, with an RMD of 21 and $34 \%$, were those that received $8 \mathrm{mgP} / \mathrm{kg}$ and either of 1 or 4 spores $/ g$, respectively. In general, however, RMD was erratic and responses to treatment combinations not significantly different from a nil RMD (data not shown). 

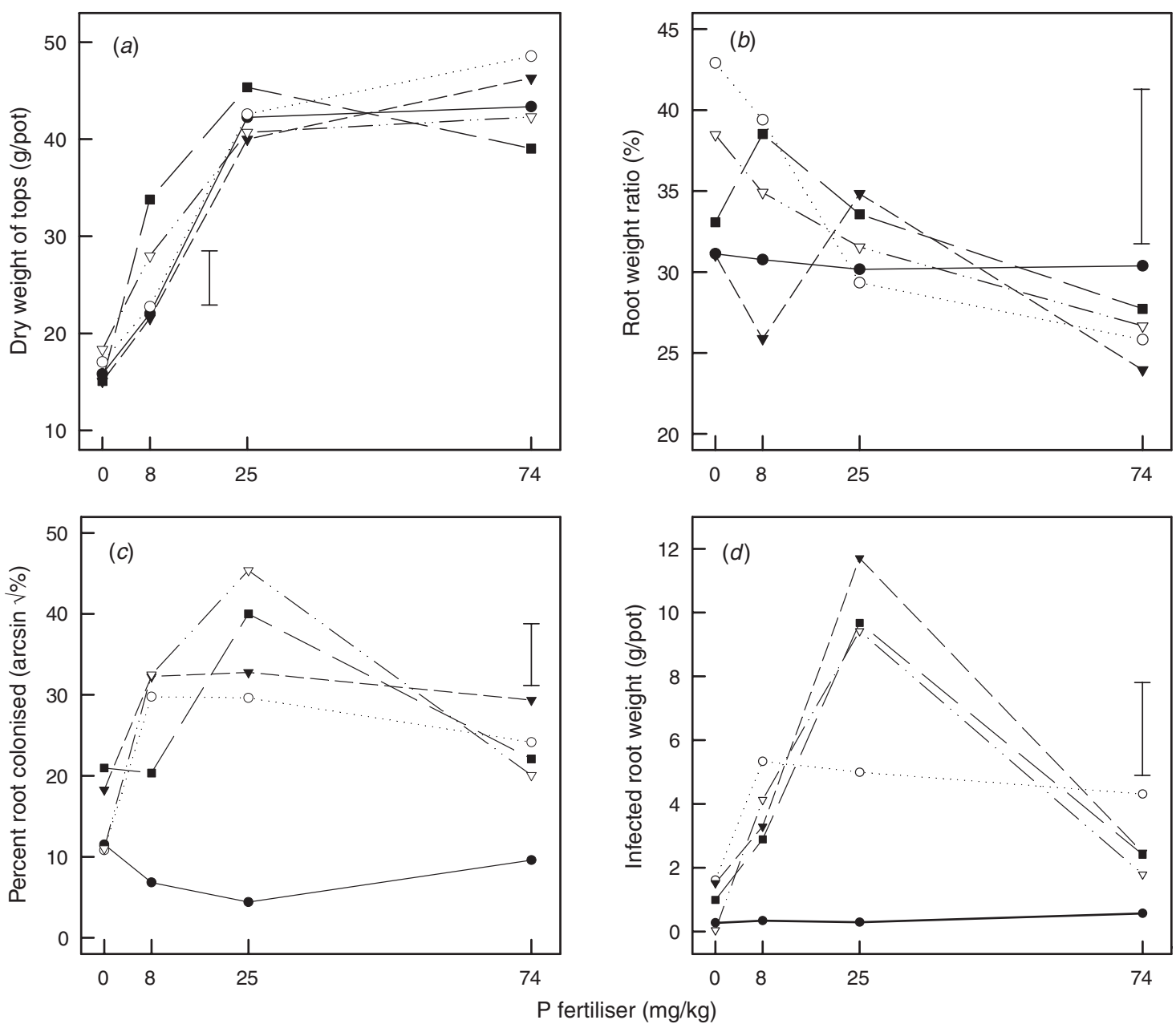

Fig. 3. Responses to $\mathrm{P}$ fertiliser $(\mathrm{mg} / \mathrm{kg})$ at 83 days after planting in $(a)$ tops dry weight, $(b)$ root weight ratio, $(c)$ percent root colonised, and $(d)$ infected root weight of sugarcane plants inoculated with $0,0.06,0.25,1$, or $4 \operatorname{spores} / \mathrm{g}(\boldsymbol{\bullet}, \bigcirc, \boldsymbol{\nabla}, \nabla$, $\mathbf{\square}$, respectively). Vertical bars represent the 1.s.d. $(P=0.05)$, and refer to the comparison of means within each figure.

Table 2. Parameters for Mitscherlich response surfaces that describe responses in dry weight of tops of sugarcane at 83 days after planting to the application of $P$ fertiliser

Parameters refer to the model $y=a-b \cdot c^{x}$ where $y$ is the dry weight of plant tops $(\mathrm{g} / \mathrm{pot})$ and $x$ is the $\mathrm{P}$ fertiliser applied $(\mathrm{mg} / \mathrm{kg})$

\begin{tabular}{lccccc}
\hline $\begin{array}{l}\text { Spore density } \\
\text { (spores/g) }\end{array}$ & $a$ & $b$ & $c$ & $r^{2}$ & $F$-ratio \\
\hline 0 & 45.2 & 31.0 & 0.94 & 0.89 & $* * *$ \\
0.06 & 50.7 & 35.0 & 0.95 & 0.83 & $* * *$ \\
0.25 & 46.6 & 31.6 & 0.94 & 0.90 & $* * *$ \\
1 & 42.8 & 25.0 & 0.93 & 0.84 & $* * *$ \\
4 & 42.1 & 27.2 & 0.85 & 0.88 & $* * *$ \\
\hline
\end{tabular}

${ }^{\mathrm{A}} \mathrm{F}$-ratio is given at $P=0.001(* * *)$.

There was no evidence for a general relationship between dry weight of tops at harvest $(y)$ and root colonisation by AM (x) (Fig. 4). Regression analyses of $\mathrm{P}$ treatments were conducted but none of these models proved significant $(P=0.05)$.
Table 3. Tillers produced (no./plant), fine root index (FRI), and $P$ concentration in the TVD leaf $(\%)$ of sugarcane plants in response to the addition of $P$ fertiliser $(0,8.2,25,74 \mathrm{mg} / \mathrm{kg})$

Values refer to the means of spore treatments

\begin{tabular}{lccc}
\hline $\begin{array}{l}\text { P fertiliser } \\
(\mathrm{mg} / \mathrm{kg})\end{array}$ & Tillers & FRI $^{\mathrm{A}}$ & $\begin{array}{c}\text { P concentration } \\
\text { in TVD leaf }\end{array}$ \\
\hline 0 & $2.9 \mathrm{a}$ & $2.0 \mathrm{a}$ & $0.08 \mathrm{a}$ \\
8.2 & $2.8 \mathrm{a}$ & $2.6 \mathrm{~b}$ & $0.10 \mathrm{~b}$ \\
25 & $3.2 \mathrm{a}$ & $3.7 \mathrm{c}$ & $0.12 \mathrm{c}$ \\
74 & $5.0 \mathrm{~b}$ & $3.6 \mathrm{c}$ & $0.17 \mathrm{~d}$ \\
1. s.d. $(P=0.05)$ & 0.6 & 0.5 & 0.01 \\
\hline
\end{tabular}

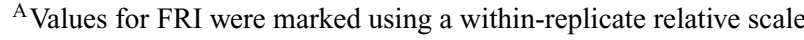
from 1 (relatively poor fine-root development) to 5 (relatively good fine-root development).

\section{Plant nutrient concentrations}

Tissue $\mathrm{P}$ concentrations responded positively to greater amounts of $\mathrm{P}$ fertiliser (Fig. 5a). All plants had tissue $\mathrm{P}$ in the 


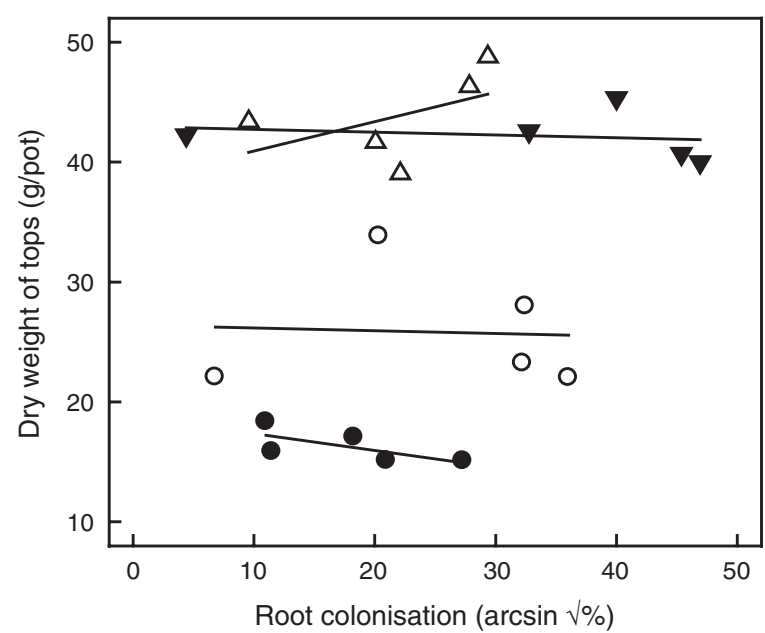

Fig. 4. Scatterplot of the dry weight of tops at harvest and the degree of root colonisation by AM. Groups relate to the addition of 4 rates of $\mathrm{P}$ fertiliser $(0,8.2,25,74 \mathrm{mg} \mathrm{P} / \mathrm{kg} ; \bullet, \bigcirc, \nabla, \triangle$, respectively). None of the regression models was significant $(P=0.05)$.

TVD leaf below $0.20 \%$. For those without AM spores, tissue $\mathrm{P}$ rose significantly as applied $P$ increased from nil to $74 \mathrm{mg} / \mathrm{kg}$ ( 0.07 v. $0.15 \% ; P<0.05)$. However, the presence of AM, irrespective of density, appeared to raise the $\mathrm{P}$ concentration of plants at the highest $\mathrm{P}$ rate (viz. $0.15-0.19 \% ; P<0.05$ ). The relationship between mean $\mathrm{P}$ concentration in the TVD leaf $(y)$ and rate of $\mathrm{P}$ application $(x)$ was best described by the Mitscherlich regression (Fig. $5 a$ ):

$$
y=0.296+0.212 \cdot 0.992^{x}\left(r^{2}=0.92 ; n=20 ; P<0.05\right)
$$

The relationship between dry weight of tops (y) and $\mathrm{P}$ concentration in the TVD leaf $(x)$ can be described, using the treatment means, by the regression (Fig. $5 b$ ):

$$
y=50.4-145 \cdot(5.4 E-9)^{x}\left(r^{2}=0.75 ; n=20 ; P<0.001\right)
$$

The critical tissue $P$ concentration, where $90 \%$ of maximal yield was obtained (i.e. $45.4 \mathrm{~g} / \mathrm{pot}$ ), is $0.17-0.18 \%$ for the TVD leaf.

When considering the means of only those plants that received AM spores, this critical tissue $\mathrm{P}$ concentration was slightly reduced to $0.15-0.16 \%$ and the relationship was defined by the regression:

$$
y=48.1-212 \cdot(2.8 E-11)^{x}\left(r^{2}=0.78 ; n=16 ; P<0.001\right)
$$

Concentrations of other nutrients also varied within the TVD leaf in response to $P$ fertiliser (Table 4). In some cases, such as $\mathrm{Ca}$, the concentration declined as greater rates of $\mathrm{P}$ were applied (e.g. $0.31 \%$ with nil P v. $0.26 \%$ with $74 \mathrm{mg} / \mathrm{kg}$ ). For others, such as K, the concentration appeared to slightly increase with $\mathrm{P}$ fertiliser $(1.44 \%$ with nil $\mathrm{P} v .1 .55 \%$ with $74 \mathrm{mg} / \mathrm{kg}$ ). Leaf tissue concentrations of Ca, K, S, Zn, Fe, Mg, and $\mathrm{Cu}$ all appeared to be above those regarded as critical in the industry (based on 3-4-month-old plants; Calcino 1994) (Table 4).

\section{Discussion}

\section{Response by sugarcane to varying $A M$ densities}

In this study, responses by sugarcane to AM spore density were generally not evident. The only significant dry weight responses to AM were observed in plants that received $8 \mathrm{mg} \mathrm{P} / \mathrm{kg}$; plants inoculated with 1 or 4 spores $/ \mathrm{g}$ produced more dry matter than those that received fewer or nil spores (Fig. 3a).
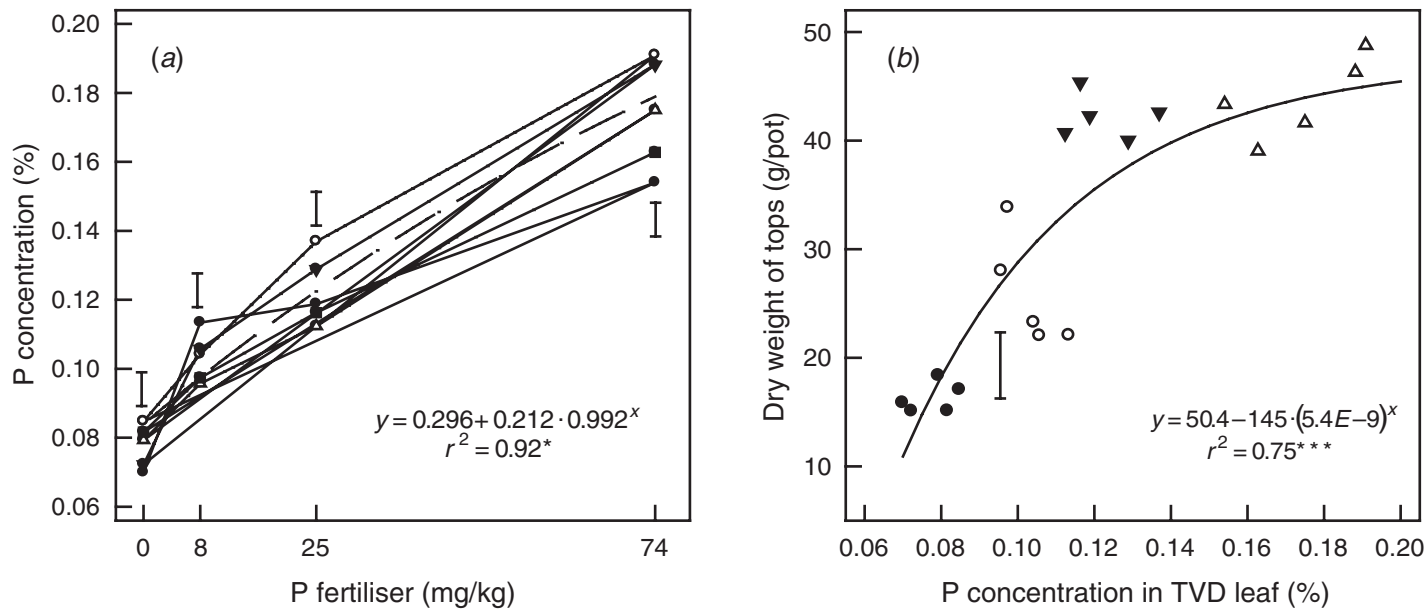

Fig. 5. Response of $(a) \mathrm{P}$ concentration in the TVD leaf to the addition of 4 rates of $\mathrm{P}$ fertiliser according to spore density $(0,0.06,0.25,1,4$ spores/g; $\boldsymbol{\bullet}, \mathbf{\nabla}, \bigcirc, \triangle, \boldsymbol{\square}$, respectively), and $(b)$ the dry weight of tops to P concentration in the TVD leaf grouped by $\mathrm{P}$ fertiliser $(0,8.2,25,74 \mathrm{mg} \mathrm{P} / \mathrm{kg} ; \bullet, O, \nabla, \Delta$, respectively). The dashed line and regression equation in (a) refer to the main effects of $\mathrm{P}$ fertiliser on the $\mathrm{P}$ concentration in the TVD leaf. 
Table 4. Nutrient concentrations found in the topmost visible dewlap leaf of sugarcane at 83 days after planting in response to $P$ fertiliser application $(0,8.2,25,74 \mathrm{mg} / \mathrm{kg})$ Values refer to the means of $+\mathrm{AM}$ and $-\mathrm{AM}$ treatments

\begin{tabular}{lccccccr}
\hline P treatment & $\mathrm{Ca}$ & $\mathrm{Mg}$ & $\mathrm{K}$ & $\mathrm{S}$ & $\mathrm{Zn}$ & $\begin{array}{c}\mathrm{Cu} \\
(\%)\end{array}$ & $\mathrm{Fe}$ \\
\hline 0 & \multicolumn{2}{c}{$\begin{array}{c}c \\
(\mathrm{mg} / \mathrm{kg})\end{array}$} \\
8.2 & $0.31 \mathrm{c}$ & 0.10 & $1.44 \mathrm{~b}$ & $0.16 \mathrm{~b}$ & $26 \mathrm{~b}$ & 4 & $71 \mathrm{~b}$ \\
25 & $0.31 \mathrm{c}$ & 0.10 & $1.41 \mathrm{~b}$ & $0.17 \mathrm{c}$ & $25 \mathrm{ab}$ & 4 & $68 \mathrm{~b}$ \\
74 & $0.25 \mathrm{a}$ & 0.10 & $1.32 \mathrm{a}$ & $0.15 \mathrm{a}$ & $22 \mathrm{a}$ & 6 & $58 \mathrm{a}$ \\
1. s.d. $(P=0.05)$ & $0.26 \mathrm{a}$ & 0.11 & $1.55 \mathrm{c}$ & $0.16 \mathrm{~b}$ & $26 \mathrm{~b}$ & 3 & $55 \mathrm{a}$ \\
Critical $^{\mathrm{A}}$ & 0.05 & n.s. & 0.09 & 0.01 & 4 & n.s. & 6 \\
\hline
\end{tabular}

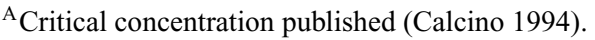

Other reports also indicate that sugarcane is poorly responsive to AM. Kelly et al. (2001) found that dry matter responses (apart from one $\mathrm{P}$ treatment) were $<10 \%$. Pinchin (1986) found that responsiveness by sugarcane to AM was $12 \%$ or less. Our study here suggests that spore density, at least with 4 spores/g or less, is not likely to be the cause for such poor responses.

A number of other reasons may be more critical. Firstly, AM colonisation appears sensitive to plant-available P. In this study, root colonisation was poorest with nil P (Fig. 3c). Smith and Read (1997) suggested that results such as these indicate that $\mathrm{P}$ availability is insufficient to sustain the association. At $74 \mathrm{mg} \mathrm{P} / \mathrm{kg}$, root colonisation by plants was also reduced (especially those with 1 or 4 spores $/ g$ ) compared with plants that received less P (Fig. 3c). The isolate may be sensitive to these higher $\mathrm{P}$ rates. Similar observations were made by Kelly et al. (2001) at the low-P rate. At $8.2 \mathrm{mg} \mathrm{P} / \mathrm{kg}$, dry weight did respond to 4 spores/g (Fig. $3 a$ ), evidence that there was enhanced $\mathrm{P}$ acquisition by the mycorrhizal root and sufficient soil-P to stimulate the association (Porter et al. 1978; Johnson and Pfleger 1992). At $25 \mathrm{mg} \mathrm{P} / \mathrm{kg}$, responses to AM were not evident despite good root colonisation (Fig. 3a,c). The root association, at this level of P, appears neither parasitic nor beneficial.

Secondly, ineffective strains of AM selectively enriched in long-term monocultured fields may cause poor or negative growth responses (Johnson and Pfleger 1992). However, results here and elsewhere (Kelly et al. 2001) indicate that $\mathrm{Gl}$. clarum can lead to positive growth responses in sugarcane, and also in corn and soybean under low-medium $P$. Despite originating from long-term monocultured fields, there is little evidence from this study to suggest that this strain is an inferior symbiont.

Thirdly, propagule densities in this study may have been insufficient to lead to a significant response by sugarcane. Reports of spore densities in soil vary markedly from $1.2 \mathrm{spores} / \mathrm{g}$ under pasture (Porter et al. 1987) to $7-20$ spores/g in soil taken from barley fields (Black and Tinker 1979). Thompson (1996) recovered about 93 spores/g from a heavy-clay Vertosol on the Darling Downs.
Thompson (1994) found that 25 spores/g soil were required for optimal growth of linseed in a Darling Downs field, and Seymour (2002) found that 8 spores of Gl. mosseae/g soil were optimal for linseed in pot culture. Hendrix et al. (1995) found that propagule densities (spores plus infected root pieces, wet-sieved from 38 to $425 \mu \mathrm{m}$ ) ranged from 0.2 to 2 propagules/g field soil for various cropping sequences in Kentucky. Kelly (1999) reported that spore numbers from sugarcane soils ranged from 1.4 to 8 spores $/ \mathrm{g}$, although it was unclear how many of these spores were non-viable or dormant. Field-sampled roots of sugarcane from northern Queensland appear not to be colonised beyond about 30\% (Kelly 1999). In this study, we achieved a $66 \%$ colonisation (or $47 \%$ with arcsin transformation, Fig. $3 c$ ) with just 0.25 spore $/ \mathrm{g}$. A propagule density of 4 spores/g appears sufficient to form a viable symbiosis.

A final mechanism for poor growth responses by sugarcane could be that sugarcane is genetically a poorly responsive host to AM. This may be due to sufficient $\mathrm{P}$ levels within the planted sett (as with cassava; Habte and Byappanahalli 1994), or an inability by sugarcane roots to rapidly receive or metabolise AM-acquired $\mathrm{P}$. The ability of cane roots to successfully host mycorrhizal fungi but demonstrate neither a carbon drain nor a $\mathrm{P}$ gain may highlight the inconsequential nature of the symbiosis in sugarcane.

\section{Evidence for AM-related growth reductions}

Evidence of yield reduction directly due to AM, at any density, was not apparent. This contrasts with slight yield reductions reported by Pinchin (1986) and Kelly et al. (2001). In addition, there was no indication that yield per se was related to root colonisation (Fig. 4). Attempts to then increase AM density through cultural practice (Thompson 1994) seem unlikely to lead to yield increases by sugarcane. Conversely, sugarcane grown in fields with high spore densities and high plant-available $\mathrm{P}$, such as long-term cane-growing soils, is unlikely to suffer a yield reduction. 


\section{Responses of sugarcane to $P$}

Sugarcane did respond positively to the addition of $\mathrm{P}$. Increased tissue $\mathrm{P}$ in the TVD leaf due to $\mathrm{P}$ addition (Fig. $5 a$ ) led to greater tops dry weight (Fig. $5 b$ ).

This study found that the overall critical tissue concentration of $\mathrm{P}$ for sugarcane was $0.17-0.18 \%$ (Eqn 5, Fig. $5 b$ ), just less than the published critical concentration for sugarcane of $0.19 \%$ (Calcino 1994). Our results are similar to critical concentrations reported by Kelly et al. (2001) for sugarcane cv. Q124, given as $0.09-0.11 \%$ for mycorrhizal plants and $0.16-0.18 \%$ for non-mycorrhizal plants.

\section{Conclusions}

This study confirms earlier reports that sugarcane is poorly responsive to AM. Spore density up to 4 spores/g soil appears unable to influence this responsiveness, either positively or negatively. Attempts to gain $\mathrm{P}$ benefits by increasing AM density through rotation are unlikely to lead to yield increases of sugarcane. Conversely, sugarcane grown in fields with high spore densities and high plant-available $\mathrm{P}$, such as long-term cane-growing soils, is unlikely to suffer a direct yield reduction from these agents.

\section{Acknowledgments}

This work was funded by the Sugar Research and Development Corporation. We are very grateful for technical assistance from Judy Bull (BSES, Tully), Janette Mercer, and Winston Bean (UQ, Brisbane), and for biometrical advice from Kerry Bell (QDPIF, Toowoomba).

\section{References}

Black R, Tinker PB (1979) The development of endomycorrhizal root systems. II. Effect of agronomic factors and soil conditions on the development of vesicular-arbuscular mycorrhizal infection in barley and on the endophyte spore density. New Phytologist 83, 401-413.

Bramley RGV, Ellis N, Nable RO, Garside AL (1996) Changes in soil chemical properties under long-term sugar cane monoculture and their possible role in sugar yield decline. Australian Journal of Soil Research 34, 967-984. doi: 10.1071/SR9960967

Bramley RGV, Roth CH (2002) Land use impact on water quality in an intensively managed catchment in the Australian humid tropics. Marine and Freshwater Research 53, 931-940. doi: 10.1071/MF01242

Bramley RGV, Roth CH, Wood AW (2003) Risk assessment of phosphorus loss from sugarcane soils - a tool to promote improved management of P fertiliser. Australian Journal of Soil Research 41, 627-644. doi: 10.1071/SR02099

Bramley RGV, Wood AW (1996) More precise P fertiliser recommendations to minimize potential downstream impacts of the sugar industry. In 'Downstream effects of land use'. (Eds HM Hunter, AG Eyles, GE Rayment) pp. 269-272. (DNR: Brisbane, Qld)

Bramley RGV, Wood AW, Cristaudo R (1995) Improving the precision of phosphorus fertiliser recommendations for sugar cane. Proceedings of Australian Society of Sugar Cane Technologists Conference 17, 179-186. doi: 10.1071/SR02099
Calcino DV (1994) 'Australian sugarcane nutrition manual.' (SRDC/BSES: Brisbane, Qld)

Cannon MG, Smith CD, Murtha GG (1992) 'Soils of the Cardwell-Tully area, north Queensland.' CSIRO Division of Soils Report 115. (CSIRO: Canberra, ACT)

Fiske ML, Thompson JP (1988) Single-endophyte pot-culture at the Queensland Wheat Research Institute. In 'Abstracts of a Symposium on Vesicular-Arbuscular Mycorrhizae (VAM) in Agriculture and Horticulture'. pp. 40. (AIAS: Toowoomba, Qld)

Giovannetti M, Mosse B (1980) An evaluation of techniques for measuring vesicular arbuscular mycorrhizal infection in roots. New Phytologist 84, 489-500.

Habte M, Byappanahalli MN (1994) Dependency of cassava (Manihot esculenta Crantz) on vesicular-arbuscular mycorrhizal fungi. Mycorrhiza 4, 241-245. doi: 10.1007/s005720050027

Hendrix JW, Guo BZ, An ZQ (1995) Divergence of mycorrhizal fungal communities in crop production systems. In 'The significance and regulation of soil biodiversity'. (Eds HP Collins, GP Robertson, ML Klug) pp. 131-140. (Kluwer Academic Publishers: Dordrecht, The Netherlands)

INVAM (International Culture Collection of Arbuscular and Vesicular-Arbuscular Mycorrhizal Fungi) (2002) URL: www.invam.caf.wvu.edu

Isbell RF (1996) 'The Australian Soil Classification.' (CSIRO Publishing: Melbourne, Vic.)

Johnson CM, Ulrich A (1959) II. Analytical methods for use in plant analysis. Californian Agricultural Experimental Station Bulletin 766, 26-78.

Johnson NC (1993) Can fertilization of soil select less mutualistic mycorrhizae? Ecological Applications 3, 749-757.

Johnson NC, Pfleger FL (1992) Vesicular-arbuscular mycorrhizae and cultural stress. In 'Mycorrhizae in sustainable agriculture'. (Eds GJ Bethlenfalvay, RG Linderman) pp. 71-99. (ASA: Madison, WI)

Kelly RM (1999) The effects of vesicular-arbuscular mycorrhizal fungi on the nutrition of sugarcane. $\mathrm{PhD}$ thesis, University of Queensland, Australia.

Kelly RM, Edwards DG, Thompson JP, Magarey RC (2001) Responses of sugarcane, maize, and soybean to phosphorus and vesiculararbuscular mycorrhizal fungi. Australian Journal of Agricultural Research 52, 731-743. doi: 10.1071/AR00131

Magarey RC (1996) Microbiological aspects of sugarcane yield decline. Australian Journal of Agricultural Research 47, 307-322. doi: 10.1071/AR9960307

Modjo HS, Hendrix JW (1986) The mycorrhizal fungus Glomus macrocarpum as a cause of tobacco stunt disease. Phytopathology 76, 688-691.

Phillips JM, Hayman DS (1970) Improved procedures for clearing roots and staining parasitic and vesicular-arbuscular mycorrhizal fungi for rapid assessment of infection. Transactions of the British Mycological Society 55, 158-161.

Pinchin JE (1986) Effect of inoculation with different species of vesicular-arbuscular mycorrhizae on the early growth, development, and mineral nutrition of sugarcane. MSc thesis, University of Hawaii, USA.

Plenchette C, Fortin JA, Furlan V (1983) Growth responses of several plant species to mycorrhizae in a soil of moderate P-fertility. I. Mycorrhizal dependency under field conditions. Plant and Soil 70, 199-209.

Porter WM, Robson AD, Abbott LK (1978) Effect of rate of application of superphosphate on populations of vesiculararbuscular endophytes. Australian Journal of Experimental Agriculture and Animal Husbandry 18, 573-578. doi: 10.1071/ EA9780573 
Porter WM, Robson AD, Abbott LK (1987) Field survey of the distribution of vesicular-arbuscular mycorrhizal fungi in relation to soil pH. Journal of Applied Ecology 24, 659-662.

Rayment GE, Higginson FR (1992) 'Australian laboratory handbook of soil and water chemical methods.' (Inkata Press: Melbourne, Vic.)

Reghenzani JR (1993) A survey of the nutritional status of North Queensland sugarcane soils with particular reference to zinc. Proceedings of the Australian Society of Sugar Cane Technologists Conference 15, 298-304.

Seymour NP (2002) Response of linseed to vesicular-arbuscular mycorrhizae, phosphorus and zinc in a vertisol. $\mathrm{PhD}$ thesis, University of Queensland, Australia.

Smith SE, Read DJ (1997) 'Mycorrhizal symbiosis.' 2nd edn (Academic Press: San Deigo, CA)

Thompson JP (1990) Soil sterilisation methods to show VAmycorrhizae aid $\mathrm{P}$ and $\mathrm{Zn}$ nutrition of wheat in vertisols. Soil Biology and Biochemistry 22, 229-240. doi: 10.1016/00380717(90)90092-E

Thompson JP (1994) What is the potential for management of mycorrhizas in agriculture? In 'Management of mycorrhizas in agriculture, horticulture and forestry'. (Eds AD Robson, LK Abbott, N Malajczuk) pp. 191-200. (Kluwer Academic Publishers: Dordrecht, The Netherlands)
Thompson JP (1996) Correction of dual phosphorus and zinc deficiencies of linseed (Linum usitatissimum L.) with cultures of vesicular-arbuscular mycorrhizal fungi. Soil Biology and Biochemistry 28, 941-951. doi: 10.1016/00380717(95)00185-9

Tommerup IC (1992) Methods for the study of the population biology of vesicular-arbuscular mycorrhizal fungi. Methods in Microbiology 24, 23-51.

Whitehead AG, Hemming JR (1965) A comparison of some quantitative methods of extracting small vermiform nematodes from soil. Annals of Applied Biology 55, 25-38.

Wood AW (1988) Phosphate sorption characteristics of sugarcane soils in the Ingham area. Proceedings of Australian Society of Sugar Cane Technologists Conference 10, 111-117.

Manuscript received 13 August 2004, accepted 15 August 2005 